A Short History of the Ismailis 
ISLAMIC SURVEYS

General Editor

Carole Hillenbrand 


\section{A Short History of the Ismailis}

Traditions of a Muslim Community

Farhad Daftary 


\section{To Farimah}

\section{(C) Farhad Daftary, 1998}

Edinburgh University Press 22 George Square, Edinburgh

Typeset in Linotron Trump Mediaeval by Koinonia, Bury, and printed and bound in Great Britain by CPI Antony Rowe, Eastbourne, East Sussex

A CIP record for this book is available from the British Library

Transferred to digital print 2008

ISBN 074860904 o (hardback)

ISBN 0748606874 (paperback)

The right of Farhad Daftary to be identified as author of this work has been asserted in accordance with the Copyright, Designs and Patents Act 1988 